\title{
ARFIMA Modelling for Tectonic Earthquakes in The Maluku Region*
}

\author{
Pemodelan ARFIMA untuk Kejadian Gempa Bumi Tektonik di Wilayah \\ Maluku
}

\section{Ferry Kondo Lembang ${ }^{1 \ddagger}$, Lexy Janzen Sinay², and Asrul Irfanullah ${ }^{3}$}

\author{
${ }^{1}$ Program Studi Statistika FMIPA Universitas Pattimura, Indonesia \\ ${ }^{2}$ Program Studi Statistika FMIPA Universitas Pattimura, Indonesia \\ ${ }^{3}$ Program Studi Statistika FMIPA Universitas Pattimura, Indonesia \\ ${ }^{\ddagger}$ corresponding author: ferrykondolembang@gmail.com
}

Copyright ( 2021 Ferry Kondo Lembang, Lexy Janzen Sinay, and Asrul Irfanullah. This is an openaccess article distributed under the Creative Commons Attribution License, which permits unrestricted use, distribution, and reproduction in any medium, provided the original work is properly cited.

\begin{abstract}
Maluku Province is one of the regions in Indonesia with a very active and very prone earthquake intensity because it is a meeting place for 3 (three) plates, namely the Eurasian, Pacific and Australian plates. In the last 100 years, the history of tectonic earthquakes with tsunamis that occurred in Indonesia was $25-30 \%$ occurring in the Maluku Sea and Banda Sea. Based on this fact, this study aims to analyze the incidence of tectonic earthquakes that occurred in the Maluku region and its surroundings using the Autoregressive Fractionally Integrated Moving Averages (ARFIMA) model which has the ability to explain long-term time series data (long memory). The results of the research data analysis show that the best model for predicting the number of tectonic earthquakes that occur in Maluku and its surroundings is ARFIMA $(0 ; 0.712 ; 1)$ with an MSE value of 0.1156 . Meanwhile, the best model for predicting the average magnitude of the number of tectonic earthquakes that occurred in Maluku and its surroundings is ARFIMA $(0 ;-3,224 \times 10-9 ; 1)$ with an MSE value of 0.01237 . Based on the two best models, the prediction results obtained from the number of tectonic earthquakes and the average magnitude of the number of tectonic earthquakes that occurred in Maluku and its surroundings for the next three periods, namely the first period there were 31 tectonic earthquakes with an average magnitude of $4.38481 \mathrm{SR}$. the second period there were 32 tectonic earthquakes with an average magnitude of 4.38407 , and the third period there were 32 tectonic earthquakes with an average magnitude of 4.38333 .
\end{abstract}

Keywords: ARFIMA, Earthquake, Maluku Province, MSE, Tectonic.

\footnotetext{
* Received: Aug 2020; Reviewed: Des 2020; Published: Mar 2021
} 


\section{Pendahuluan}

Indonesian Journal of Statistics and Its Applications: diterbitkan berkala 3 (tiga) kali dalam setahun yang memuat tulisan ilmiah yang berhubungan dengan bidang statistika dan aplikasinya. Artikel yang dimuat berupa hasil penelitian bidang statistika dan aplikasinya dengan topik (tapi tidak terbatas): rancangan dan analisis percobaan, metodologi survey dan analisis, riset operasi, data mining, pemodelan statistika, komputasi statistika, time series dan ekonometrika, serta pendidikan statistika.

Laut Banda dan pulau-pulau di sekitarnya, khususnya Provinsi Maluku merupakan wilayah yang berada di pertemuan 3 (tiga) lempeng yaitu lempeng Eurasia, Pasifik dan Australia (Gambar 1). Pertemuan lempeng-lempeng tersebut menyebabkan intensitas kejadian gempa sangat aktif dan sangat rawan. Ahli gempabumi dan tsunami di dalam dan luar negeri telah melakukan berbagai penelitian gempa bumi dan tsunami di Laut Banda, Laut Seram dan Laut Maluku Utara dan Kepulauan di Maluku berdasarkan catatan sejarah gempa bumi dan tsunami, kondisi geoteknologi dan geografis kepulauan di Maluku.

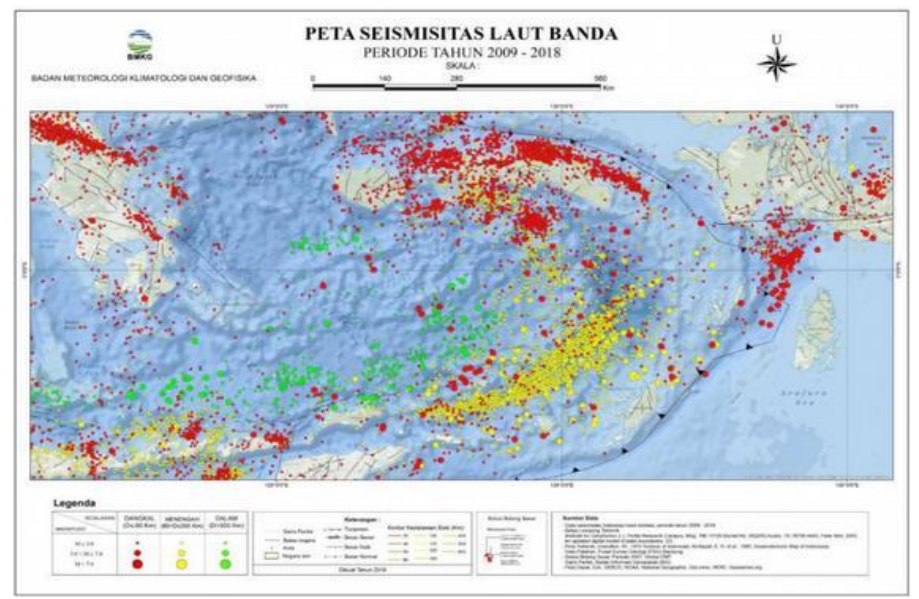

Gambar 1: Peta Seismitas Laut Banda Tahun 2009-2018

Berdasarkan sejarah kejadian gempa tektonik dengan tsunami yang terjadi di Indonesia selama kurun waktu 100 tahun terakhir sebanyak 25-30\% terjadi di wilayah Laut Maluku dan Laut Banda. Dimana sumber utamanya adalah zona benturan di Laut Banda, zona subduksi di wilayah utara Pulau Seram. Gempa Bumi Besar yang terjadi di wilayah Maluku yaitu Gempa Ambon pada tanggal 17 Februari 1674 dimana disusul dengan gelombang tsunami tinggi yang menerjang Laut Banda dan kejadian gempabumi magnitudo 6.82 pada tanggal 26 September 2019 pukul 06.46.45 WIB bersumber dari koordinat $3.38 \mathrm{LS}$ dan $128.43 \mathrm{BT}$; atau $40 \mathrm{~km}$ timur laut AmbonMaluku dengan kedalaman $10 \mathrm{~km}$. Gempa melanda Kota Ambon, Maluku Tengah dan Seram Bagian Barat yang mengakibatkan 41 jiwa meninggal dunia, 1.602 luka-luka, dan 230.000 lebih orang mengungsi. Selain berdampak korban, gempa juga mengakibatkan lebih dari 12.000 rumah dan 500 fasilitas umum serta fasilitas sosial terdampak.

Menurut data Badan Meteorologi Klimatologi Geofisika (BMKG) tercatat dalam satu dekade di wilayah Indonesia terjadi peningkatan frekuensi gempa dimana sepanjang tahun 2019 wilayah Indonesia diguncang sebanyak 11.573 gempabumi 
dengan beragam kekuatan. Jumlah ini melonjak tajam daripada tahun 2009 yang mencapai 4.390 kali gempa (Gambar 2). Sedangkan wilayah timur Indonesia, stasiun pencatatan gempa Ambon mencatat sebanyak lebih dari 5.000 kali gempa bumi mengguncang wilayah Maluku sepanjang tahun 2019. Jumlah prosentase kejadian gempa di wilayah Maluku (Laut Banda) menunjukkan 44,06\% dibandingkan total kejadian gempa di seluruh Indonesia pada tahun 2019. Beberapa penelitian terkait analisis kejadian gempa tektonik pernah dilakukan antara lain oleh Rizal et al. (2016) yang melakukan analisis kejadian gempa bumi tektonik di wilayah Pulau Sumatera menggunakan metode ARFIMA dimana diperoleh hasil peramalan terhadap banyaknya gempa tektonik dan rata-rata magnitudo dari banyaknya gempa tektonik yang bersifat fluktuatif. Penelitian lainnya oleh Wattimanela \& Latupeirissa (2020) dimana menganalisis karakteristik gempa tektonik yang terjadi di Provinsi Nusa Tenggara Barat dan sekitarnya.



Gambar 2: Trend Gempa Indonesia Tahun 2013-2019

Merujuk fenomena data diatas, maka penelitian ini bertujuan untuk menganalisis kejadian gempa bumi tektonik yang terjadi di wilayah Maluku dengan menggunakan Metode Autoregressive Fractionally Integrated Moving Averages (ARFIMA). Model ARFIMA diperkenalkan pertama kali oleh Granger dan Joyeuk (1980) untuk mengatasi kelemahan metode Autoregressive Integrated Moving Averages (ARIMA). ARIMA hanya menjelaskan data deret waktu jangka pendek (short memory) sedangkan ARFIMA mampu menjelaskan data deret waktu jangka panjang (long memory). Dalam beberapa kasus metode ARFIMA cenderung mendapatkan hasil yang lebih baik dibandingkan metode peramalan deret waktu lainnya (Ishida \& Watanabe, 2009); (Siew et al., 2008); (Sari, 2017).

\section{Metodologi}

\subsection{Bahan dan Data}

Bahan dan Data yang digunakan dalam penelitian ini adalah jenis data sekunder yang diperoleh dari United States Geological Survey (USGS) dengan situs http://earthquake.usgs.gov/earthquakes/search/. Data tersebut yaitu data banyaknya gempa tektonik dan rata-rata magnitudo yang terjadi setiap bulan di wilayah Maluku dan sekitarnya dengan besar magnitudo $\geq 1.0$ SR Periode Januari 2000- Desember 2018.

\subsection{Metode Penelitian}

\section{Analisis Deret Waktu (Time Series)}

Analisis deret waktu pertama kali diperkenalkan oleh George E. P. Box dan Gwilym M. 
Jenkins pada tahun 1970 melalui buku yang berjudul Time Series Analysis : Forecasting and Control. Deret waktu (time series) merupakan serangkaian data pengamatan yang terjadi berdasarkan indeks waktu secara berurutan dengan interval waktu tetap. Analisis deret waktu adalah salah satu prosedur statistika yang diterapkan untuk meramalkan struktur probabilistik keadaan yang akan terjadi di masa yang akan datang dalam rangka pengambilan keputusan.

\section{ARFIMA (Autoregressive Fractionally Integrated Moving Average)}

Model ARFIMA merupakan pengembangan dari model ARIMA. Suatu proses dikatakan mengikuti model ARFIMA apabila nilai d adalah riil. ARFIMA disebut juga ARIMA yang nilai d tidak hanya berupa nilai integer, melainkan termasuk juga nilainilai riil yang disebabkan oleh adanya memori jangka panjang. Menurut Barkoulas dan Baum (1996) bentuk model ARFIMA $(p, d, q)$ dapat ditulis sebagai berikut :

$$
\phi(B) \nabla^{d} Y_{t}=\theta(B) a_{t}, t=1,2, \ldots, T
$$

Dengan tingkat integrasi d merupakan bilangan riil dan $a_{t} \square I I D\left(0, \sigma_{t}^{2}\right)$. Filter pembeda $\nabla^{d}$ dalam rumus diatas dikatakan sebagai Long Memory Filter (LMF) yang menggambarkan adanya ketergantungan jangka panjang dalam deret.

Tahapan penelitian yang dilakukan meliputi :

\section{a. Pemeriksaan Kestasioneran Data}

Model-model peramalan data time series seperti ARIMA dan ARFIMA umumnya didasarkan atas asumsi stasioner dalam rata-rata (mean) dan varians (Sinay et al., 2020). Data disebut stasioner apabila plot data yang terbentuk bergerak konstan, baik secara rata-rata (mean) maupun varians. Sedangkan apabila plot data bergerak tidak konstan, maka data yang membentuk plot tersebut dikatakan tidak stasioner. Pengujian kestasioneran data terhadap rata-rata (mean) menggunakan Uji Augmented Dickey- Fuller (ADF) (Box, et. al, 1994) dimana perumusan hipotesinya sebagai berikut :

$H_{0}: \delta=0$ (data mengandung akar unit/data deret waktu tidak stasioner)

$H_{1}: \delta \neq 0$ (data tidak mengandung akar unit/data deret waktu stasioner)

Dengan statistik uji : $t=\frac{\delta}{\partial(\hat{m})}$ dimana kriteria pengujian tolak $\mathrm{H}_{0}$ jika $\left|t_{\delta}\right| \geq\left|t_{\text {tabel }}\right|$. Apabila diperoleh data tida $E$ \$alsioner terhadap varians, maka dapat dilanjutkan dengan melakukan Transformasi Box-Cox (Wei, 2006). Sedangkan untuk ketidakstasioneran data terhadap rata-rata, dilakukan differencing.

\section{b. Identifikasi Pola Long Memory}

Mengidentifikasi data time series yang mengandung pola long memory adalah dengan melihat plot Autocorelattion Function (ACF) yang tidak turun secara eksponensial akan tetapi turun melambat secara hiperbolik (Hosking, 1981). Selain pengidentifikasian pola long memory secara visual, dapat dilakukan dengan perhitungan Statistik Hurst $(H)$ dengan ketentuan dimana jika nilai $H=0,5$ maka data bersifat short memory, data bersifat intermediate memory jika nilai $\mathrm{H}$ berada pada interval $0<H<0,5$, dan apabila nilai $H$ terletak dalam interval $0,5<\mathrm{H}<1$ berarti data bersifat long memory (Palma, 2007).

\section{c. Tahapan Metode ARFIMA}

Dalam mengidentifikasi suatu model yang paling tepat dari berbagai model yang ada, metode ARFIMA menggunakan sebuah pendekatan iteratif. model sementara yang telah dipilih perlu diuji lagi dengan data aktual apakah model sementara tersebut 
sudah layak atau belum. Suatu model dianggap layak jika residual (selisih hasil prediksi dan dengan actual) terdistribusi secara acak dan berdistribusi normal (Hartini \& Nurmaleni, 2018). Tahapan penerapan metode ARFIMA secara berturut-turut yaitu pendugaan parameter $d$, pemilihan model terbaik, diagnostick checking model terbaik, dan prediksi (forecasting). Model yang telah memenuhi syarat (parameter signifikan, residual memenuhi asumsi white noise) akan dibandingkan berdasarkan kriteria Mean Square Error (MSE) minimum (Matdoan et al., 2019). Setelah terpilih model ARFIMA $(p, d, q)$ terbaik berdasarkan nilai MSE minimum, maka langkah selanjutnya adalah melakukan prediksi (forecasting). Pada penelitian ini akan dilakukan forecasting terhadap banyaknya gempa tektonik dan rata-rata magnitudo dari banyaknya gempa tektonik yang terjadi di wilayah Maluku dan Sekitarnya.

\section{Hasil dan Pembahasan}

Dalam sub bab hasil dan pembahasan ini akan dibahas tentang analisis data ratarata gempabumi tektonik yang terjadi setiap bulan di wilayah Maluku dan sekitarnya periode Januari Tahun 2000 sampai dengan Desember Tahun 2018. Analisis data dilakukan untuk mendapatkan model terbaik dan memprediksi rata-rata banyaknya gempabumi tektonik setiap bulan dan rata-rata magnitudo dari banyaknya gempa tektonik yang terjadi di wilayah Maluku dan Sekitarnya menggunakan metode ARFIMA.

\subsection{Pengujian Kestasioneran Data}

Plot data time series pada Gambar 1 dan Gambar 2 diduga data banyaknya gempa tektonik yang terjadi dan rata-rata magnitudo telah stasioner dalam rata-rata (mean) sebab trendnya cenderung datar. Sedangkan untuk stasioner dalam varian terindikasi belum terpenuhi sebab terdapat beberapa data yang menjurai baik keatas maupun kebawah.
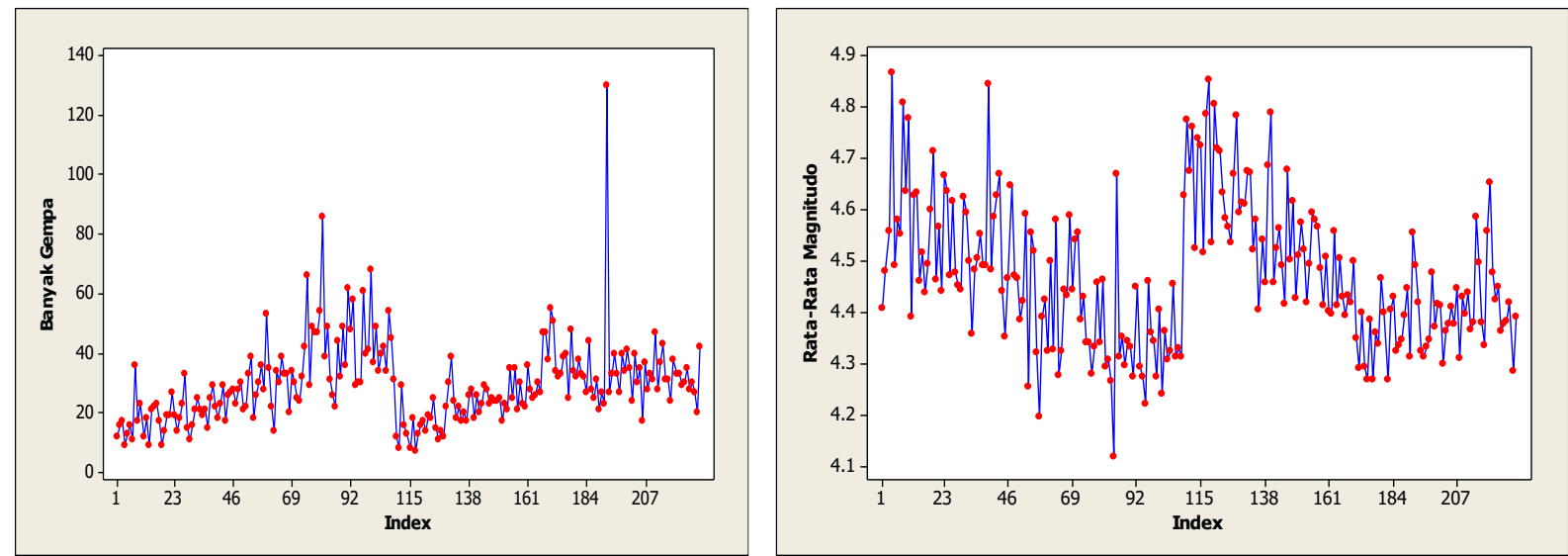

Gambar 3: Plot Data Banyaknya Gempa Gambar 4: Plot Rata-Rata Magnitudo Gempa Pengecekan kebenaran kestasioneran data tidak hanya dapat dilihat berdasarkan plot data akan tetapi juga dengan melakukan uji statistik Transformasi Box-Cox untuk pengujian kestasioneran varian, sedangkan uji ADF untuk pengujian kestasioneran rata-rata. Informasi pengecekan kestasioneran data dalam varians ditunjukkan pada Tabel 1. 
Tabel 1: Transformasi Box-Cox pada data banyaknya Gempa Tektonik yang terjadi dan Rata-Rata Magnitudo yang terjadi setiap bulan di wilayah Maluku.

\begin{tabular}{llcc}
\hline & \multicolumn{1}{c}{ Data } & Nilai $\lambda$ & Stasioner \\
\hline Sebelum & Banyaknya Gempa Tektonik & 0 & Tidak \\
\cline { 2 - 4 } Transformasi & $\begin{array}{l}\text { Rata-Rata Magnitudo Dari } \\
\text { Banyaknya Gempa Tektonik }\end{array}$ & 1 & Ya \\
\hline Transformasi & Banyaknya Gempa Tektonik & 1 & Ya \\
\cline { 2 - 4 } Pertama & $\begin{array}{l}\text { Rata-Rata Magnitudo Dari } \\
\text { Banyaknya Gempa Tektonik }\end{array}$ & 1 & Ya \\
\hline
\end{tabular}

Dari tabel 1 diatas diperoleh informasi bahwa untuk data rata-rata magnitudo banyaknya gempa tektonik telah stasioner dalam varians dan tidak perlu dilakukan transformasi. Sedangkan untuk data banyaknya gempa tektonik yang terjadi stasioner dalam varians $(\lambda=1)$ setelah dilakukan transformasi sebanyak satu kali. Selanjutnya informasi untuk pengujian stasioner dalam rata-rata (mean) menggunakan uji ADF ditunjukkan pada Tabel 2.

Tabel 2: Uji ADF pada Banyaknya Gempa Tektonik yang Terjadi dan Rata-Rata Magnitudo yang Terjadi Setiap Bulan di Wilayah Maluku.

\begin{tabular}{|c|c|c|c|c|}
\hline Data & Nilai ADF $\left(t_{\delta}\right)$ & ttabel & p-value & Kesimpulan \\
\hline $\begin{array}{l}\text { Banyaknya } \\
\text { Tektonik }\end{array}$ & -5.993380 & 1,966 & 0,000 & Stasioner \\
\hline $\begin{array}{l}\text { Rata-Rata Magnitudo Dari } \\
\text { Banyaknya Gempa } \\
\text { Tektonik }\end{array}$ & -2.634394 & 1,966 & 0,088 & Stasioner \\
\hline
\end{tabular}

Berdasarkan hasil pengujian ADF pada Tabel 2 diperoleh bahwa nilai $\left|t_{\delta}\right| \geq\left|t_{\text {tabel }}\right|$ atau $\mathrm{p}$-value lebih kecil dari $\alpha=10 \%$ sehingga dapat disimpulkan bahwa kedua data tersebut yakni banyaknya gempa tektonik yang terjadi dan rata-rata magnitude dari banyaknya gempa tektonik yang terjadi telah stasioner dalam rata-rata (mean).

\subsection{Identifikasi Long Memory}

Selanjutnya untuk mengetahui apakah data memenuhi asumsi data time series jangka panjang (long memory) maka perlu dilakukan pengujian long memory. Terdapat dua pendekatan untuk pengujian long memory antara lain dengan melihat plot ACF-nya, dimana disimpulkan data time series mengandung long memory apabila plot ACF data tidak turun secara ekspnensial melainkan turun lambat atau hiperbolik. Berikut dari Gambar 3 dan Gambar 4 ditunjukkan plot ACF dari kedua data.

Dari hasil plot ACF kedua data menunjukkan fungsi autokorelasinya (ACF) turun secara lambat atau hiperbolik yang mengidentifikasi bahwa data banyaknya kejadian gempa tektonik yang terjadi dan rata-rata magnitude gempa tektonik di wilayah Maluku memiliki ketergantungan jangka panjang atau long memory process. Selain dilihat melalui plot fungsi autokorelasi kedua data yang turun secara lambat atau hiperbolik, untuk mengidentifikasi adanya ketergantungan jangka panjang atau long memory process dilakukan dengan perhitungan Uji Statistik Hurst $(H)$. Hasil perhitungan nilai Hurst $(H)$ disajikan pada Tabel 3. 

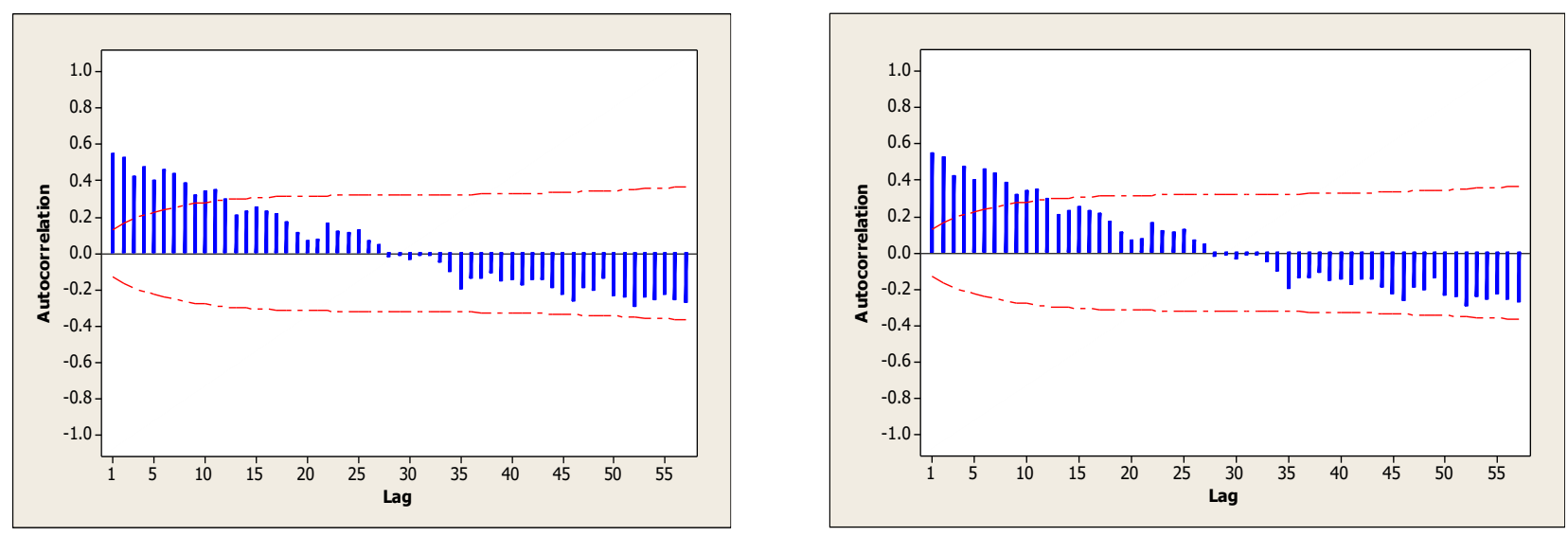

Gambar 5: Plot ACF banyak kejadian gempa (kiri) \& rata-rata magnitude (kanan)

Tabel 3: Statistik Hurst dari Banyaknya Gempa Tektonik yang Terjadi dan Rata-Rata Magnitudo dari Banyaknya Gempa yang Terjadi Setiap Bulan di Wilayah Maluku.

\begin{tabular}{lcc}
\multicolumn{1}{c}{ Data } & Nilai $\boldsymbol{H}$ & Long Memory \\
\hline Banyaknya Gempa Tektonik & 0,910 & Ya \\
\hline Rata-Rata Magnitudo Dari & 0,578 & Ya \\
Banyaknya Gempa Tektonik & & \\
\hline
\end{tabular}

Berdasarkan hasil perhitungan Uji Statistik Hurst $(H)$ yang dilakukan diperoleh nilai Hurst $(H)$ untuk kedua data berturut-turut adalah 0,910 dan 0,578, yang berarti berdasarkan kriteria Uji Statistik Hurst $(H)$ disimpulkan bahwa data banyaknya kejadian gempa tektonik yang terjadi dan rata-rata magnitude banyaknya kejadian gempa tektonik di wilayah Maluku dan sekitarnya mengandung long memory process dikarenakan nilai $H$ berada pada interval $0,5<\mathrm{H}<1$.

\subsection{Tahapan Metode ARFIMA}

Oleh karena data mengandung efek long memory, maka metode peramalan yang tepat untuk digunakan adalah dengan menggunakan metode ARFIMA. Dalam proses peramalan, untuk menangkap long memory pada data, metode ARFIMA menggunakan nilai parameter pembeda (d) dalam bentuk pecahan yang diperoleh dari metode Geweke Porter-Hudak (GPH). Tabel 4 berikut dibawah ini memperlihatkan nilai $d$ taksiran untuk kedua data dengan menggunakan bantuan software $\mathrm{R}$.

Tabel 4: Taksiran Pembeda Fraksional (d) dari Data Banyaknya Gempa Tektonik yang Terjadi dan Rata-Rata Magnitudo dari Banyaknya Gempa yang Terjadi Setiap Bulan di Wilayah Maluku.

\begin{tabular}{lccc}
\hline \multicolumn{1}{c}{ Data } & Nilai $\boldsymbol{d}$ & $\begin{array}{c}\text { Asymptotic } \\
\text { Standard Deviation }\end{array}$ & SE Deviation \\
\hline Banyaknya Gempa Tektonik & 0,712 & 0,219 & 0,268 \\
\hline Rata-Rata Magnitudo Dari & $-3,224 \times 10^{-9}$ & 0,219 & $2,444 \times 10^{-9}$ \\
Banyaknya Gempa Tektonik & & & \\
\hline
\end{tabular}

Dari Tabel 4 diperoleh nilai $d$ taksiran untuk banyaknya gempa tektonik yang terjadi dan Rata-Rata Magnitudo dari banyaknya gempa tektonik yang terjadi yakni masing-masing sebesar 0,712 dan $-3,224 \times 10^{-9}$. Nilai $d$ tersebut digunakan untuk mendifferencingkan data. Langkah selanjutnya dalam tahapan ini adalah melakukan identifikasi model ARFIMA sementara berdasarkan plot ACF dan PACF yang disajikan 
pada Gambar 5 dan Gambar 6.

Informasi yang bisa diperoleh dari Gambar 5, Plot ACF data transformasi banyaknya gempa tektonik yang terjadi menunjukkan bahwa pada lag 1 signifikan dan cut off pada lag 2 lalu kembali siginifkan pada lag 3. Sedangkan plot PACF menunjukkan bahwa pada lag 1,2, dan 3 signifikan dan cut off pada lag 4 lalu signifikan kembali pada lag ke-5 dan ke-6. Berdasarkan dua informasi ini dapat diidentifikasi bahwa kemungkinan model ARFIMA untuk data transformasi banyaknya gempa tektonik yang terjadi adalah ARFIMA $(0 ; 0,712 ; 1)$, ARFIMA $(3 ; 0,712 ; 0)$, dan ARFIMA $(3 ; 0,712 ; 1)$.
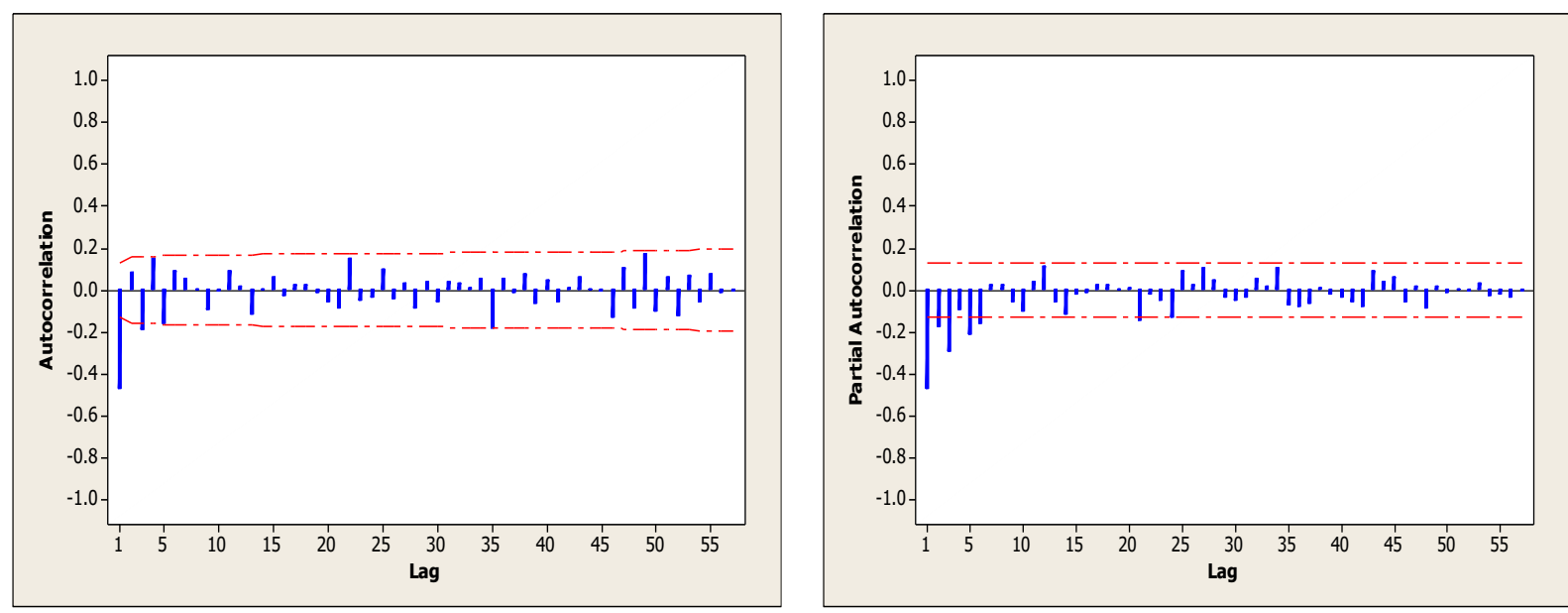

Gambar 6: Plot ACF dan PACF Banyaknya Gempa Tektonik Yang Terjadi
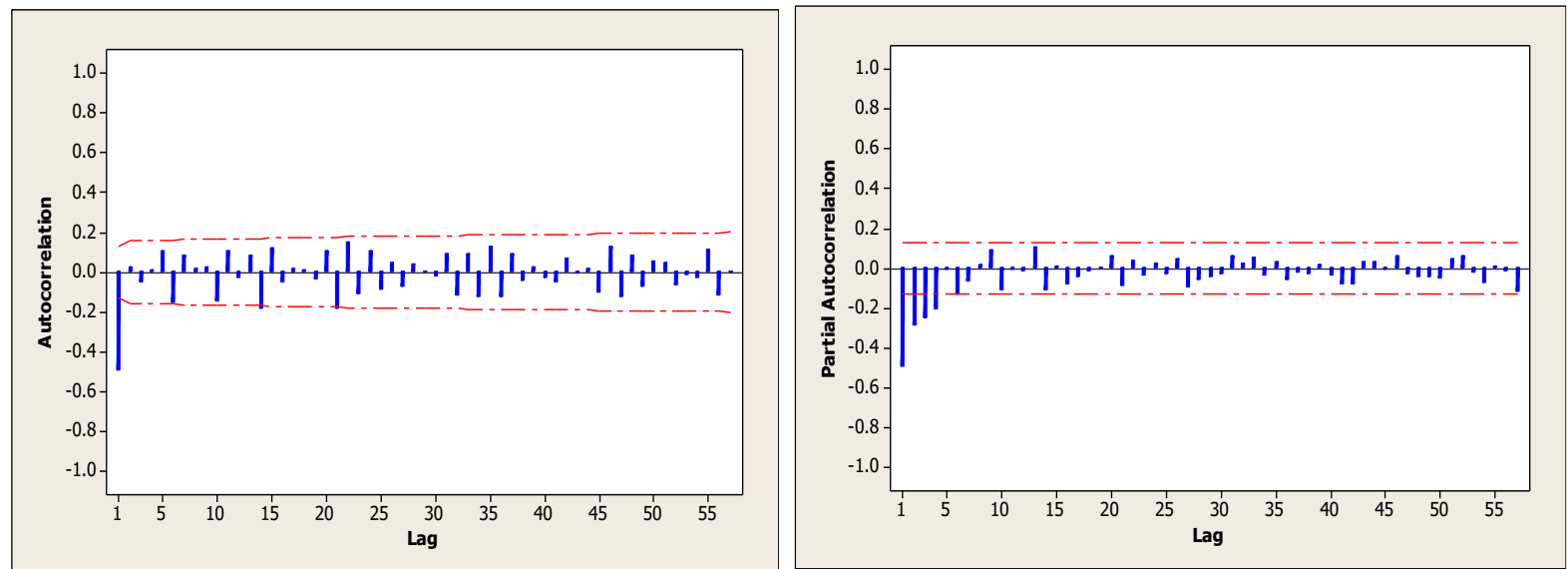

Gambar 7: Plot ACF dan PACF Rata-Rata Magnitudo Banyaknya Gempa Tektonik Yang Terjadi

Informasi yang bisa diperoleh dari Gambar 6 diatas Plot ACF data Rata-Rata Magnitudo dari Banyaknya Gempa yang Terjadi Setiap Bulan di Wilayah Maluku menunjukkan bahwa pada lag 1 signifikan dan cut off pada lag 2. Sedangkan plot PACF menunjukkan bahwa pada lag 1,2,3, dan 4 signifikan dan cut off pada lag 5 . Berdasarkan dua informasi ini dapat diidentifikasi bahwa kemungkinan model ARFIMA untuk data data Rata-Rata Magnitudo dari Banyaknya Gempa yang Terjadi Setiap Bulan di Wilayah Maluku adalah ARFIMA $\left(0 ;-3,224 \times 10^{-9} ; 1\right)$, ARFIMA $\left(4 ;-3,224 \times 10^{-9}\right.$ ;0), dan ARFIMA $\left(4 ;-3,224 \times 10^{-9} ; 1\right)$. 
Setelah mendapatkan kemungkinan model terbaik ARFIMA dari kedua data tersebut, maka untuk menentukan keterpilihan model terbaik perlu dilakukan estimasi dan pengujian signifikansi parameter dari kemungkinan model terbaik yang telah ditentukan. Tabel 5 berikut menunjukkan hasil estimasi dan pengujian signifikansi parameter dari ketiga kemungkinan model terbaik data banyaknya Gempa yang terjadi Setiap Bulan di Wilayah Maluku dan sekitarnya.

Tabel 5: Estimasi dan Pengujian Parameter dari Banyaknya Gempa Tektonik

\begin{tabular}{cccccc}
\hline Model & Parameter & Koefisien & t-hitung & $p$-value & hasil Uji \\
\hline ARFIMA (0; 0,712;1) & $\mathrm{C}$ & 0.003435 & 0.60 & 0.549 & Tidak Sig. \\
\cline { 2 - 6 } & $\mathrm{MA}(1)$ & 0.7478 & 16.96 & 0.000 & Sig. \\
\hline ARFIMA (3;0,712;0) & $\mathrm{C}$ & 0.00844 & 0.37 & 0.714 & Tidak Sig. \\
\cline { 2 - 6 } & $\mathrm{AR}(1)$ & -0.6098 & -9.48 & 0.000 & Sig. \\
\cline { 2 - 6 } & $\mathrm{AR}(2)$ & -0.3392 & -4.66 & 0.000 & Sig. \\
\cline { 2 - 6 } & $\mathrm{AR}(3)$ & -0.2959 & -4.59 & 0.000 & Sig. \\
\hline ARFIMA (3;0,712;1) & $\mathrm{C}$ & 0.004084 & 0.62 & 0.537 & Tidak Sig. \\
& $\mathrm{AR}(1)$ & 0.0047 & 0.04 & 0.967 & Tidak Sig. \\
& $\mathrm{ARR}(2)$ & 0.0138 & 0.15 & 0.881 & Tidak Sig. \\
& $\mathrm{AR}(3)$ & -0.1701 & -2.13 & 0.034 & Sig. \\
\hline & $\mathrm{AA}(1)$ & 0.7062 & 7.28 & 0.000 & Sig. \\
\hline
\end{tabular}

Berdasarkan Tabel 5 diatas maka diperoleh model terbaik sementara yaitu ARFIMA $(0 ; 0,712 ; 1)$ dan ARFIMA $(3 ; 0,712 ; 0)$ dikarenakan seluruh parameter dari kedua model signifikan pada $\alpha=10 \%$. Sehingga untuk memilih model terbaiknya adalah dengan cara melihat nilai Mean Square Error (MSE) minimum dari kedua model tersebut. Berdasarkan hasil analisis menggunakan software minitab 16 diperoleh nilai MSE ARFIMA $(0 ; 0,712 ; 1)$ sebesar 0,1156 , sedangkan nilai MSE ARFIMA $(3 ; 0,712 ; 0)$ sebesar 0,1200 . Oleh sebab itu, dapat disimpulkan bahwa model terbaik untuk data banyaknya kejadian gempa tektonik yang terjadi Maluku dan sekitarnya adalah model ARFIMA $(0 ; 0,712 ; 1)$.

Langkah yang sama dilakukan untuk data rata-rata magnitudo banyaknya kejadian gempa tektonik yang terjadi di Maluku dan sekitarnya dengan melakukan estimasi dan pengujian signifikansi parameter dari kemungkinan model terbaik yang telah diperoleh dimana disajikan pada Tabel 6 .

Tabel 6: Estimasi dan Pengujian Parameter dari Rata-Rata Magnitudo

\begin{tabular}{|c|c|c|c|c|c|}
\hline Model & Parameter & Koefisien & t-hitung & $p$-value & hasil Uji \\
\hline \multirow[t]{2}{*}{ ARFIMA $\left(0 ;-3,224 \times 10^{-9} ; 1\right)$} & C & -0.000741 & -0.43 & 0.671 & Tidak Sig. \\
\hline & MA (1) & 0.7661 & 17.98 & 0.000 & Sig. \\
\hline \multirow[t]{5}{*}{ ARFIMA $\left(4 ;-3,224 \times 10^{-9} ; 0\right)$} & C & -0.002126 & -0.29 & 0.775 & Tidak Sig. \\
\hline & AR (1) & -0.7684 & -11.77 & 0.000 & Sig. \\
\hline & AR (2) & -0.5611 & -7.18 & 0.000 & Sig. \\
\hline & AR (3) & -0.4251 & -5.44 & 0.000 & Sig. \\
\hline & AR (4) & -0.2201 & -3.37 & 0.001 & Sig. \\
\hline \multirow[t]{6}{*}{ ARFIMA $\left(4 ;-3,224 \times 10^{-9} ; 1\right)$} & C & -0.001220 & -0.38 & 0.703 & Tidak Sig \\
\hline & AR (1) & -0.2227 & -1.08 & 0.282 & Tidak Sig. \\
\hline & AR (2) & -0.1656 & -1.03 & 0.305 & Tidak Sig. \\
\hline & AR (3) & -0.1587 & -1.25 & 0.211 & Tidak Sig. \\
\hline & AR (4) & -0.0489 & -0.47 & 0.640 & Tidak Sig. \\
\hline & MA (1) & 0.5689 & 2.87 & 0.004 & Sig. \\
\hline
\end{tabular}

Berdasarkan Tabel 6 diatas, maka diperoleh model terbaik sementara yaitu ARFIMA $\left(0 ;-3,224 \times 10^{-9} ; 1\right)$ dan $\left(4 ;-3,224 \times 10^{-9} ; 0\right)$ dikarenakan seluruh parameter dari 
kedua model signifikan pada $\alpha=10 \%$ Untuk memilih model terbaiknya adalah dengan cara melihat nilai MSE terkecil dari kedua model tersebut. Berdasarkan hasil analisis menggunakan software minitab 16 diperoleh nilai MSE ARFIMA $\left(0 ;-3,224 \times 10^{-9} ; 1\right)$ sebesar 0.01237 , sedangkan nilai MSE ARFIMA $\left(4 ;-3,224 \times 10^{-9} ; 0\right)$ sebesar 0.01249 . Oleh sebab itu, dapat disimpulkan bahwa model terbaik untuk data rata-rata magnitudo banyaknya kejadian gempa tektonik yang terjadi Maluku dan sekitarnya adalah model ARFIMA $\left(0 ;-3,224 \times 10^{-9} ; 1\right)$.

Setelah mendapatkan model terbaik dari kedua data tersebut, maka langkah yang harus dilakukan sebelum melakukan prediksi (forecasting) yakni diagnostic checking (pengujian kelayakan model). Diagnostic checking yang dilakukan meliputi uji asumsi residual memenuhi white noise (residual bersifat acak) dan berdistribusi normal. Untuk pengujian residual memenuhi asumsi white noise digunakan Statistik Uji Ljung-Box Pierce, sedangkan untuk pengujian berdistribusi normal atau tidak digunakan uji Kolmogorov-Smirnov. Hasil uji White Noise disaijikan melalui Tabel 7.

Tabel 7: Uji White Noise Kedua Data

\begin{tabular}{ccccccc}
\hline & \multicolumn{3}{c}{ Banyaknya Gempa Tektonik } & \multicolumn{3}{c}{ Rata-Rata Magnitudo } \\
\cline { 2 - 7 } Lag & \multicolumn{3}{c}{ ARFIMA $(0 ; 0,712 ; 1)$} & \multicolumn{3}{c}{ ARFIMA $\left(0 ;-3,224 \times 10^{-9} ; 1\right)$} \\
\cline { 2 - 7 } & $\chi_{\text {hit }}^{2}$ & p-value & White Noise & $\chi_{\text {hit }}^{2}$ & p-value & White Noise \\
\hline 12 & 15.4 & 0.587 & Ya & 10.9 & 0.367 & Ya \\
\hline 24 & 33.1 & 0.362 & Ya & 25.6 & 0.268 & Ya \\
\hline 36 & 55.9 & 0.292 & Ya & 37.7 & 0.303 & Ya \\
\hline 48 & 67.1 & 0.549 & Ya & 46.7 & 0.442 & Ya \\
\hline
\end{tabular}

Berdasarkan hasil analisis pengujian residual saling bebas (white noise) pada Tabel 7 diperoleh kesimpulan bahwa kedua model telah memenuhi asumsi residual saling bebas (white noise) dimana terlihat dari nilai p-value setiap lag lebih besar dari $\alpha=10 \%$. Selanjutnya pengujian normalitas residual disajikan pada Tabel 8.

Tabel 8: Uji Normalitas Kedua Data

\begin{tabular}{llcc}
\hline \multicolumn{1}{c}{ Data } & \multicolumn{1}{c}{ Model } & p-value & Normal \\
\hline Banyaknya Gempa Tektonik & ARFIMA $(0 ; 0,712 ; 1)$ & 0,088 & Tidak \\
\hline Rata-Rata Magnitudo & ARFIMA $\left(0 ;-3,224 \times 10^{-9} ; 1\right)$ & 0,010 & Tidak \\
\hline
\end{tabular}

Hasil pengujian normalitas residual yang ditunjukkan pada Tabel 8, dipereh kesimpulan bahwa kedua model belum memenuhi kenormalan residual dimana terlihat dari nilai $\mathrm{p}$-value masing-masing kurang dari $\alpha=10 \%$. Walaupun dari tahapan diagnostic checking (pengujian kelayakan model) kedua model hanya memenuhi asumsi residual saling bebas (white noise), akan tetapi dapat disimpulkan bahwa kedua model sudah cukup baik untuk dipakai sebagai model dalam memprediksi kejadian gempa tektonik di Wilayah Maluku dan sekitarnya. Tabel 9 menunjukkan hasil prediksi dari penelitian.

Tabel 9: Hasil prediksi kejadian gempa tektonik di Wilayah Maluku dan Sekitarnya

\begin{tabular}{ccc}
\hline \multirow{2}{*}{ Periode } & \multicolumn{2}{c}{ Prediksi } \\
\cline { 2 - 3 } & Banyaknya Gempa Tektonik & $\begin{array}{c}\text { Rata-rata Magnitudo dari Banyaknya } \\
\text { Gempa Tektonik }\end{array}$ \\
\hline Jan'2019 & $31 \mathrm{kali}$ & 4,38481 \\
\hline Feb'2019 & $32 \mathrm{kali}$ & 4,38407 \\
\hline Mar'2019 & $32 \mathrm{kali}$ & 4,38333 \\
\hline
\end{tabular}




\section{Simpulan}

Berdasarkan hasil penelitian yang diperoleh, maka dapat ditarik kesimpulan bahwa model terbaik untuk banyaknya gempa tektonik yang terjadi setiap bulan di wilayah Maluku periode bulan Januari 2000 - Desember 2018 adalah ARFIMA $(0 ; 0,712 ; 1)$ atau $(1-B)^{0,712} Y_{t}=(1-0,7478 B) a_{t}$ dengan nilai MSE 0,1156. Sedangkan model terbaik untuk rata-rata magnitudo gempa tektonik yang terjadi setiap bulan di wilayah Maluku periode bulan Januari 2000- Desember 2018 adalah ARFIMA $\left(0 ;-3,224 \times 10^{-9} ; 1\right)$ atau $(1-B)^{-3,224 \times 10^{-9}} Y_{t}=(1-0,7761 B) a_{t}$ dengan nilai MSE 0,01237. Hasil peramalan banyaknya gempa tektonik yang terjadi setiap bulan di wilayah Maluku periode bulan Januari 2000- Desember 2018 terjadi peningkatan nilai dari bulan Januari-Maret 2019. Sedangkan hasil peramalan rata-rata magnitudo gempa tektonik yang terjadi setiap bulan di wilayah Maluku periode Januari 2000- Desember 2018 terjadi penurunan nilai dari bulan Januari-Maret 2019.

Ucapan Terima Kasih. Terima kasih penulis ucapkan kepada Dekan FMIPA Unpatti atas bantuan pembiayaan penelitian ini melalui Anggaran PNBP FMIPA Tahun 2019.

\section{Daftar Pustaka}

Hartini, D., \& Nurmaleni, N. (2018). Penerapan Model Autoregressive Fractionally Integrated Moving Average (ARFIMA) dalam Prakiraan Data Suku Bunga PUAB (Pasar Uang Antar Bank). LOGIK@, 8(1): 24-35.

Ishida, I., \& Watanabe, T. (2009). Modeling and Forecasting the Volatility of the Nikkei 225 realized Volatility using the ARFIMA-GARCH model.

Matdoan, M. Y., Balami, A., \& Talakua, M. (2019). Pemodelan Regresi Nonparametrik Spline Truncated Pada Faktor-Faktor Yang Mempengaruhi Pertumbuhan Ekonomi Di Provinsi Maluku. VARIANCE: Journal of Statistics and Its Applications, 1(1): 2737.

Palma, W. (2007). Long-memory time series: theory and methods (Vol. 662). John Wiley \& Sons.

Rizal, J., Nugroho, S., \& Irwanto, A. (2016). Analisis Kejadian Gempa Bumi Tektonik di Wilayah Pulau Sumatera. Jurnal Matematika, 6(1): 1-14.

Sari, A. P. (2017). Perbandingan aplikasi model Arima dan Arfima pada kasus data harga saham PT. Telekomunikasi Indonesia Persero/Aprilita Permata sari (PhD Thesis). Universitas Negeri Malang.

Siew, L. Y., Chin, L. Y., \& Wee, P. M. J. (2008). ARIMA and integrated ARFIMA models for forecasting air pollution index in Shah Alam, Selangor. Malaysian Journal of Analytical Sciences, 12(1): 257-263.

Sinay, L. J., Lembang, F. K., Aulele, S. N., \& Mustamu, D. (2020). Analisis Curah Hujan Bulanan di Kota Ambon Menggunakan Model Heteroskedastisitas: Sarima-Garch. MEDIA STATISTIKA, 13(1): 68-79.

Wattimanela, H., \& Latupeirissa, S. (2020). Analysis of Tectonic Earthquake Characteristics in The Province of Nusa Tenggara Barat Indonesia and Its Surroundings. Journal of Physics: Conference Series, 1463(1), 012002. IOP Publishing.

Wei, W. W. (2006). Time series analysis. In The Oxford Handbook of Quantitative Methods in Psychology: Vol. 2. 